
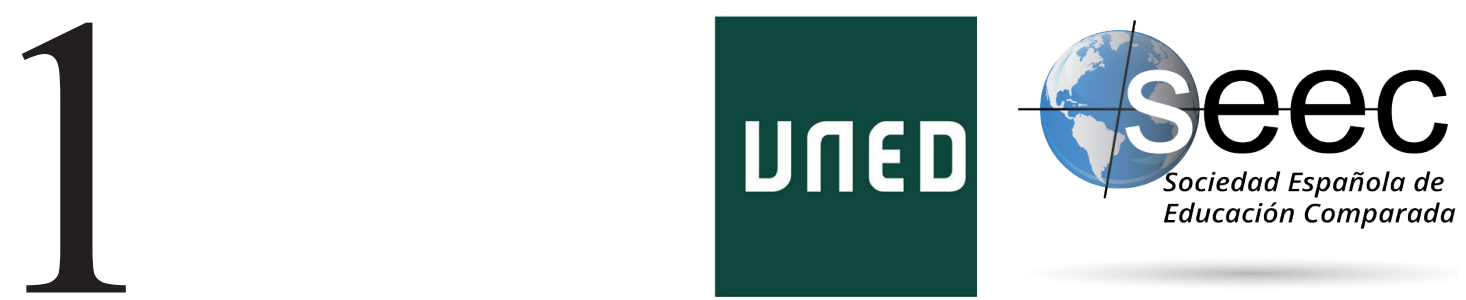

\title{
Editorial: Empires and Education
}

Editorial: Imperios y Educación

\section{Robert Cowen*}

DOI: $10.5944 /$ reec.31.2018.22037

\section{Recibido: 15 de marzo de 2018 Aceptado: 9 de mayo de 2018}

\footnotetext{
* Robert Cowen is Professor Emeritus at the University College London, Institute of Education, where (in what was then called the Institute of Education, University of London) he has been a specialist in comparative education since 1976. He has also had the privilege of residing or working in various academic or consultancy capacities for considerable periods of time in Argentina, Australia, Brazil, China, Japan, South Korea, Sri Lanka, and the USA, as well as several countries in Europe. He is an Honorary Member of the Comparative Education Society in Europe and Chair of the Editorial Board of Comparative Education. His latest (2018) publications include 'Embodied Comparative Education', Comparative Education, 54(1), 10-25. Datos de contacto: E-mail: robert.cowen@ucl.ac.uk
} 
First, I should like to thank María José García Ruiz and Javier M. Valle López, Editors of the Revista Española de Educación Comparada (REEC) for the invitation to take up the theme of 'education and empire'. The invitation was a surprise and a great privilege. I accepted immediately; knowing I would worry later. What I worried about later, of course, was what to propose to colleagues who might be potential authors.

The problem - granted that anyone I chose to approach would already have an interest in the theme of empire- is immediate: there have been quite a lot of empires in the world in the last few thousand years. I did not push the idea hard with myself, but one list could begin: the Abyssinian, the Belgian, the Cambodian, the Danish, the Egyptian... and so on. The second obvious possibility was to choose more recent but neglected empires (such as the Imperial Japanese and Nazi empires) and ask what kinds of education were distributed to whom, and why, inside those empires. The third instant answer was to concentrate on, say, four of the big empires created by European powers as they expanded on a world stage, maybe setting in tension two different interpretative perspectives on one particular Empire (such as the French or the British).

I then realised that anxiety had edged me into a cliché: that the approach of the project should be historical. Clearly there would have been advantages to insisting on an historical approach for all of the contributions: the amount of historical material easily available is enormous. Solid, well referenced, articles could have been read side-by-side giving a traditional 'comparative' perspective. Putting side by side, for example, what the French did to create educational systems in Algeria with descriptions of how the British 'built' educational systems in Ghana, India, Kenya, Nigeria would need steady scholarship and good narrative skills, but such a project was clearly possible. However, the cost would have been high. There are a lot of implicit assumptions if that strategic approach is the only one used for all articles: for example, time is linear, the space which is described is the space of the imperial actor, and comparative education describes 'the educational system'.

Thus gradually a view of the possibilities of the project emerged. Some historical papers, certainly. But perhaps ask for some articles which were not informed principally by an historical perspective? Maybe a sociologist or an anthropologist, thinking comparatively, could offer a distinctive perspective on the theme of education and empire? And - speaking of 'education'- why the 'education system': what about identities, traditions, rituals, cultures and resistances captured in tensions in education; what about childhood or adolescence, gender and race?

And above all, what about the big words: Empire and Imperialism and Colonialism and 'education-as-it-changes' within such forms of power? Rather surprisingly, comparative educationists have given very little attention to classic forms of the flows of international power and educational shapes within 'Empires' and, while the word colonialism has been used in the title of some books within comparative education, the word 'Imperialism' is rare (even if post-colonialism has now a considerable literature).

There are at least two obvious reasons why the words 'Empire' and 'Imperialism' are relatively rare. One is that comparative education (in the form of what is called in English 'international and comparative education') has spent a great deal of time 'developing' le tiers monde; without emphasising that what many people used to call the third world was once part of 'old-fashioned' Empires before international politics shifted into new forms of imperium within the ideology of 'development'. Hence the new excitement about post-colonialism; albeit before Empires have been fully studied. 
The second obvious reason why classical Empires -such as the Austro-Hungarian, the French, the Ottoman, the Roman, the Spanish- have been relatively invisible is that comparative education, notably English-language 'comparative education', has tended to lose its historical gaze. However, the question of what was done to children in the name of 'Empire' needs to be retained along with a nervousness lest we are doing the same sort of things now under new names.

By 2018, therefore, it is timely to rescue historical perspectives which 'bear witness' and to stress the ways in which international political and economic power re-shape educational systems, but to do this, on this occasion, with maximum flexibility and openness of approach.

Of course, there needed to be some general alertness among the authors to simple questions. Some were sketched in an introductory letter to authors: what kinds of 'education' were distributed within Empires and why and to whom; did the forms of education shift over time and were they different in different parts of 'the Empire'; what were the unifying political ideologies, and perhaps religions, that underpinned the distribution of education in which language(s) and, within 'an Empire', what were some of the rituals and the symbols and pedagogic styles which shaped educational transmission? Those are big questions. However, the note to authors finished with the suggestion that "perhaps the point would be to keep our initial analyses as simple as possible this time; not as complex as possible. There is so little work on classical Empires-and-education that bringing some essays about Empires together and juxtaposing them in the same publication is a perfectly proper and sensible first step for us".

And that is more or less what has happened. A wide range of intellectual perspectives has been brought to bear: Anselmo Paolone uses anthropology as his main perspective; Ron Goodenow whose main books were written in his capacity as an historian, takes a view of changes over time; Iveta Silova and Garine Palandjian come close to starting their thinking from their own biographies. Similarly, there is marvellous counterpoint: analyses of two empires - the American and the Soviet- that tended to avoid calling themselves 'empires' can be read next to two empires which were very self-consciously Empires: the Spanish, thoughtfully analysed here by Alberto Martínez Boom and the British, for which Les Bash offers a complex analysis. We are also privileged here to have permission from the author Ana Isabel Madeira (and the publishing house, Springer) to reprint a fascinating analysis of colonial educational discourses in the French and Portuguese empires in Africa, which opens up yet another way to think about 'education and empire'.

And that is the point of the articles taken together. They do not cohere; they are not written to a common formula; they cannot be read as if they are traditional narratives about the 'educational system' that can be juxtaposed, termed 'comparative', and thought of as having provided an abc of education and empire. The articles are not even intended to cohere. The articles, as a group, explode like fireworks in the sky rather than, nailed to a post with the label 'empire' on it, whirr around and around themselves until the small flame burns out.

The articles can be read and understood with a growing sense of excitement that there is something complex worth exploring here, with no Stanley bringing the project to a rather abrupt halt by saying 'Dr Livingstone, I presume?' These articles permit an old and rather neglected topic - but one of major contemporary relevance, given new 'empires of the mind'- to be seen in fresh ways. Soon, next time, in the future, we might 
take up some of the theoretical complexities of writing comparative and transnational histories of education, we should worry about what historical sociology as a field of study might suggest as an approach, we could wonder if the Austro-Hungarian or Ottoman Empires suggest different ways to think about the theme of 'education and Empire'. (They do.) However, for the moment, let us simply watch the fireworks and enjoy their variety and complexity. Tomorrow we can ask ourselves why we enjoyed the display. 